Non-Defaultable Debt and Sovereign Risk

Juan Carlos Hatchondo, Leonardo Martinez, and

Yasin Kursat Onder 
IMF Institute for Capacity Development

\title{
Non-defaultable debt and sovereign risk
}

\author{
Prepared by Juan Carlos Hatchondo, Leonardo Martinez, and Yasin Kursat Onder ${ }^{1}$
}

Authorized for distribution by Jorge Roldos

October 2014

\begin{abstract}
This Working Paper should not be reported as representing the views of the IMF. The views expressed in this Working Paper are those of the author(s) and do not necessarily represent those of the IMF or IMF policy. Working Papers describe research in progress by the author(s) and are published to elicit comments and to further debate.

We quantify gains from introducing non-defaultable debt as a limited additional financing option into a model of equilibrium sovereign risk. We find that, for an initial (defaultable) sovereign debt level equal to 66 percent of trend aggregate income and a sovereign spread of 2.9 percent, introducing the possibility of issuing non-defaultable debt for up to 10 percent of aggregate income reduces immediately the spread to 1.4 percent, and implies a welfare gain equivalent to a permanent consumption increase of 0.9 percent. The spread reduction would be only $0.1(0.2)$ percentage points higher if the government uses nondefaultable debt to buy back (finance a "voluntary" debt exchange for) previously issued defaultable debt. Without restrictions to defaultable debt issuances in the future, the spread reduction achieved by the introduction of non-defaultable debt is short lived. We also show that allowing governments in default to increase non-defaultable debt is damaging at the time non-defaultable debt is introduced and inconsequential in the medium term. These findings shed light on different aspects of proposals to introduce common euro-area sovereign bonds that could be virtually non-defaultable.
\end{abstract}

JEL Classification Numbers: F30, F34.

Keywords: sovereign default, sovereign debt, Eurobonds, red bonds, blue bonds, buyback, voluntary debt exchange

Author's E-Mail Address:juanc.hatchondo@gmail.com, 1martinez4@,imf.org, yko2@georgetown.edu

\footnotetext{
${ }^{1}$ For comments and suggestions, we thank Tamon Asonuma, Petya Koeva Brooks, Luc Eyraud, Julio Escolano, Atish Ghosh, Pablo Guerron-Quintana, Vikram Haksar, Mariusz Jarmuzek, Genevieve Verdier, and seminar participants at the IMF Institute for Capacity Development and the Atlanta Fed's Americas Center and NYU's Stern 2nd Annual Workshop on International Economics. Remaining mistakes are our own. The views expressed herein are those of the authors and should not be attributed to the IMF, its Executive Board, its management, or the Central Bank of Turkey.
} 
Contents

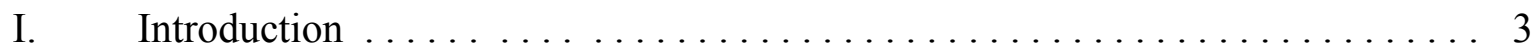

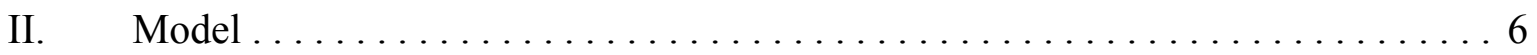

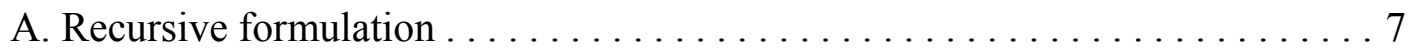

B. Recursive equilibrium . . . . . . . . . . . . . . . 9

III. Calibration ................................ 9

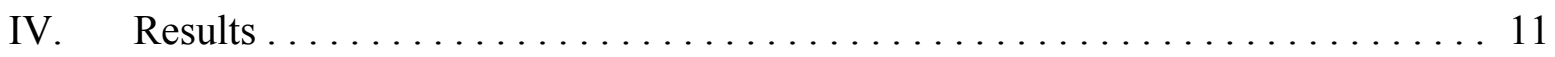

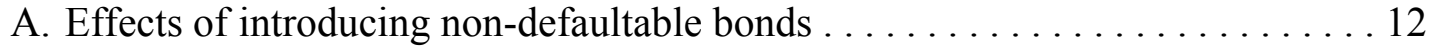

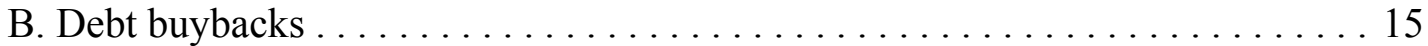

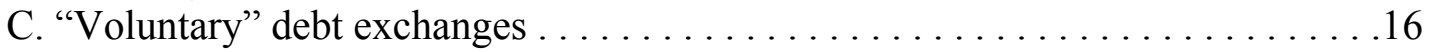

D. Long-run effect of non-defaultable on default risk . . . . . . . . . . 18

E. Voluntary debt exchanges with a limit for defaultable debt . . . . . . . . 20

F. Issuances of non-defaultable bonds during defaults . . . . . . . . . . . 21

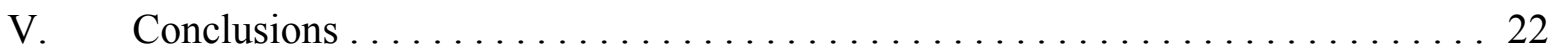

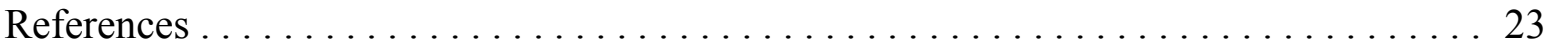

Tables

1. Parameter values . . . . . . . . . . . . . . . . . . . . . 11

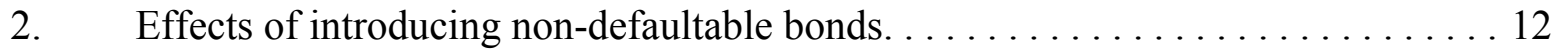

3. Effects of introducing non-defaultable bonds with a defaultable-debt buyback . . 15

4. Effects of introducing non-defaultable bonds with a "voluntary" debt exchange . . 18

5. Effects of introducing non-defaultable bonds with a limit for defaultable debt . . . 21

Figures

1. Debt after the introduction of non-defaultable bonds $\ldots \ldots \ldots \ldots \ldots \ldots$

2. Default decision with and without non-defaultable bonds . . . . . . . . . . 14

3. Debt after the introduction of non-defaultable bonds through a buyback . . . . . 16

4. Sovereign spread after the introduction of non-defaultable bonds . . . . . . . . . . 19 


\section{Introduction}

We quantify gains from introducing a limited non-defaultable financing option into a sovereign default framework à la Eaton and Gersovitz (1981) (commonly used to evaluate sovereign debt policy). The government can issue both long-term defaultable debt and non-defaultable debt, with the latter issuances restricted by an exogenous limit.

Our findings shed light on different aspects of proposals to introduce common euro-area sovereign bonds (henceforth Eurobonds). Most Eurobonds proposals include the introduction of guarantees with the objective of reducing the risk of default for these bonds, making them virtually default-free. In fact, these proposals often view Eurobonds as an alternative safe-haven to U.S. treasuries.

Discussions of the introduction of Eurobonds started soon after the introduction of the Euro. Eurobonds are viewed not only as a response to current events in Europe, but also as a key element for fiscal unions. Furthermore, it is expected that Eurobonds could help stabilize government debt markets, support monetary policy transmission, and promote financial stability and integration (EC, 2014).

Brunnermeier et al. (2011) and Claessens et al. (2012) present a detailed analysis of recent Eurobond proposals. Philippon and Hellwig (2011) propose the mutualization of short-term debt of a member state of up to 10 percent of its GDP. Similarly, the "Blue-Red bond" proposal (Delpla and von Weizscker, 2010) involves the mutualization of the debt of a member state of up to 60 percent of its GDP. In November 2011, the German Council of Economic Experts put forward for discussion the idea that European leaders consider a potential mechanism whereby the portion of debt of a member state in excess of 60 percent of its GDP would be refinanced through a temporary joint European Redemption Fund (Bofinger et al., 2011).

We intend to inform these policy discussions with a formal analysis of the effects of introducing non-defaultable debt. Thus, our analysis of Eurobonds is only partial: while we study the effects of introducing a limited non-defaultable financing option, we do not study any cost or difficulty of introducing Eurobonds. In particular, we do not deal with moral hazard or political opposition due to intergovernmental guarantees (EC, 2014). It may well be that these moral hazard concerns have prevented the mutualization of sovereign bonds in the past. The objective of this paper is to present a quantification of the gains that could arise if these concerns were overcome, giving governments access to a new non-defaultable source of financing. Some proposals aim at improving the enforcement of Eurobond payments by earmarking fiscal revenues and using collateral (e.g., the central banks' gold reserves). Our policy experiments assume a relatively low limit for the level of non-defaultable debt (10 percent of trend aggregate income). In practice, a low limit to Eurobond issuances could help mitigate moral hazard and political opposition by eliminating a country's incentives to default on these bonds.

Formally, we study a small open economy that receives a stochastic endowment stream of a single tradable good. The government's objective is to maximize the expected utility of 
private agents. The government makes decisions on a sequential basis: each period, the government first decides whether to default (on its defaultable debt) and then decides how much to borrow. A defaulting government faces an income cost and is temporarily prevented from issuing defaultable debt. Furthermore, the defaulting government can rollover non-defaultable debt but it cannot increase the level of its non-defaultable debt while in default.

We first show that immediately after the introduction of non-defaultable debt, the spread of defaultable sovereign bonds (i.e., the difference between the sovereign bond yield and the risk-free interest rate) is reduced significantly but the reduction is short lived. Introducing the possibility of issuing non-defaultable debt for up to 10 percent of trend income reduces the interest rate spread from 2.9 percent to 1.4 percent. The spread returns to the levels displayed prior to the introduction of non-defaultable debt in less than five years. The spread reduction is short-lived because the initial reduction in the level of defaultable debt reverts over time. The government first uses the newly available non-defaultable debt financing, and the level of defaultable debt declines. But after exhausting its new source of financing, the government increases the level of defaultable debt. After five years, non-defaultable debt does not significantly change the government's ability or willingness to issue defaultable debt and face default risk.

We also find that the welfare gain from the introduction of non-defaultable debt is equivalent to a permanent consumption increase of 0.9 percent. As is standard in models of sovereign default à la Eaton and Gersovitz (1981), government borrowing is limited by endogenous and binding borrowing constraints that arise because the government cannot commit to paying its debt. Thus, the government benefits from the new borrowing opportunities implied by the introduction of non-defaultable debt.

We next focus on two alternative modalities for introducing non-defaultable debt commonly mentioned in policymakers' discussions of Eurobonds: using Eurobonds to buy back defaultable debt, and a debt exchange in which Eurobonds are swapped for defaultable debt. The key difference between these two modalities is that in the second one, it is assumed that the debt exchange does not produce capital gains (or capital losses) for the holders of defaultable debt, thus allowing for a larger reduction of defaultable debt. Following Hatchondo et al. (2014b), we refer to such exchanges as "voluntary".

We find that using non-defaultable debt issuances for 10 percent of trend income would allow the government to buy back defaultable debt for 12 percent of trend income. The model features a buyback boondoggle à la Bulow and Rogoff $(1988,1991)$ but the additional increase in sovereign bond prices implied by the debt buyback is minimal: the spread reduction at the moment non-defaultable debt is introduced is only slightly higher when the government is forced to use non-defaultable debt to buy back defaultable debt (1.6 percent instead of 1.5 percent). ${ }^{1}$ This occurs because lenders anticipate the additional

\footnotetext{
${ }^{1}$ Aguiar and Amador (2013) study disadvantages of buybacks. In contrast with their work, we focus on the costs of using non-defaultable bonds for a buyback (instead of maintaining the option of issuing nondefaultable in the future or conducting a voluntary exchange), and we present a quantitative evaluation of these costs.
} 
debt reduction implied by the buyback is only temporary (and crucially, since we model long-term debt, the price of defaultable bonds depends on default risk in all future period. Naturally, the welfare gain is lower with the buyback (0.7 percent instead of 0.9 percent): we always give the government the option to buyback defaultable debt, and the government is worse off when it is forced to do so.

Government's gains are larger when non-defaultable debt is introduced through a voluntary debt exchange. With the voluntary debt exchange the government reduces its debt level by 14 percent of trend income (instead of 12 percent with the buyback), implying a 1.7 percent spread reduction (instead of 1.6 percent with the buyback), and a welfare gain of 1.1 percent ( 0.7 with the buyback).

We also show that non-defaultable debt issuances for 10 percent of trend income could finance (through a voluntary debt exchange) a defaultable-debt reduction sufficient to implement immediately and without a consumption sacrifice a defaultable-debt limit that eliminates default risk both immediately and permanently. Commitment to fiscal rules is a central element of policy discussions on Eurobonds (Bofinger et al., 2011; Claessens et al., 2012). We assume the government can commit to a fiscal rule imposing a defaultable-debt limit of 55 percent of trend income. Introducing non-defaultable bonds together with the debt limit allows the government to reduce its debt level by 16 percent of trend income (instead of 14 percent without the limit), to 50 percent, allowing the government to implement the debt limit immediately without a consumption sacrifice. In particular, with a debt level of 50 percent and a limit of 55 percent, the government can finance a consumption increase of 5 percent of trend income. ${ }^{2}$ The welfare gain implied by these policies is 1.4 percent (instead of 1.1 percent without the debt limit).

We build on the quantitative sovereign default literature that follows Aguiar and Gopinath (2006) and Arellano (2008). Within this literature, Boz (2011) studies a model in which the government can issue both defaultable and non-defaultable debt. Boz (2011) interprets non-defaultable debt issuances as borrowing from International Financial Institutions. ${ }^{3}$ Thus, in contrast with this paper, she assumes that the issuance of risk-free debt triggers conditionality and is subject to an exogenous interest rate schedule. She focuses on changes in the debt portfolio over the business cycle. In contrast, we focus on the gains from introducing risk-free debt as a new source of financing and under different modalities of introduction. Also in contrast with Boz (2011), we assume defaultable debt is long-term and holders of defaulted debt recover a fraction of their assets when the default ends. This makes our model more suitable for quantitative analysis (for instance, we can replicate debt and spread levels observed in the data).

\footnotetext{
${ }^{2}$ The defaultable debt reduction is larger with the debt limit because the price of defaultable debt is higher with the debt limit. Therefore, with the debt limit, less defaultable debt is needed to assure that lenders do not make losses (as required by our definition of a voluntary debt exchange). In particular, after the announcement of the introduction of non-defaultable debt and the debt limit, defaultable debt becomes risk free (i.e., the sovereign spread drops to zero). Hatchondo et al. (2011) study fiscal rules in a sovereign default model without non-defaultable debt. Hatchondo et al. (2014a) argue that sovereign bond covenants could be used to improve commitment to fiscal rules.

${ }^{3}$ Dellas and Niepelt (2013) study a model in which the government can default on both official and private debt but defaulting on official debt is more costly.
} 
The rest of the article proceeds as follows. Section II. presents the model. Section III. introduces the calibration. Section IV. presents the results. Section V. concludes.

\section{Model}

The government has preferences given by

$$
\mathbb{E}_{t} \sum_{j=t}^{\infty} \beta^{j-t} u\left(c_{j}\right),
$$

where $\mathbb{E}$ denotes the expectation operator, $\beta$ denotes the subjective discount factor, and $c_{t}$ represents consumption of private agents. The utility function is strictly increasing and concave. The government cannot commit to future (default and borrowing) decisions. Thus, one may interpret this environment as a game in which the government making decisions in period $t$ is a player who takes as given the (default and borrowing) strategies of other players (governments) who will decide after $t$.

The timing of events within each period is as follows. First, the government learns the economy's income. After that, the government chooses whether to default on its (defaultable) debt. Before the period ends, the government may change its debt positions, subject to the constraints imposed by its default decision. The government can issue both defaultable and non-defaultable debt.

The economy's endowment of the single tradable good is denoted by $y \in Y \subset \mathbb{R}_{++}$. This endowment follows a Markov process.

As in Hatchondo and Martinez (2009) and Arellano and Ramanarayanan (2012), we assume that a defaultable bond issued in period $t$ promises an infinite stream of coupons, which decreases at a constant rate $\delta$. In particular, a defaultable bond issued in period $t$ promises to pay $(1-\delta)^{j-1}$ units of the tradable good in period $t+j$, for all $j \geq 1$. Hence, debt dynamics can be represented as follows:

$$
b_{t+1}=(1-\delta) b_{t}+l_{t},
$$

where $b_{t}$ is the number of defaultable coupons due at the beginning of period $t$, and $l_{t}$ is the number of defaultable long-term bonds issued in period $t$.

Each non-defaultable bond is a promise to deliver one unit of the good in the next period. There is a limit to the number of non-defaultable bonds the government can issue. This limit may depend on whether the government is in default and on the level of non-defaultable debt. These assumptions allow us to limit the issuance of non-defaultable bonds for governments in default, while still allowing these governments to roll over existing non-defaultable bonds.

Bonds are priced in a competitive market inhabited by a large number of foreign investors. Thus, bond prices are pinned down by the foreign investors' zero-expected-profit condition. Foreign investors are risk-neutral and discount future payoffs at the rate $r$. 
When the government defaults, it does so on all current and future defaultable debt obligations. This is consistent with the observed behavior of defaulting governments and it is a standard assumption in the literature. ${ }^{4}$

A default event triggers exclusion from the defaultable-debt market for a stochastic number of periods. Furthermore, income is given by $y-\phi(y)$ in every period in which the government is excluded from the defaultable-debt market. Starting the first period after the default period, with a constant probability $\psi \in[0,1]$, the government may be presented with the opportunity of regaining access to the defaultable-debt market. In order to regain access, the government needs to give to the holders of defaulted bonds, defaultable bonds promising to pay $b_{R}$ in the current period. This is a simple way of capturing debt exchanges that occur after default episodes.

Assuming that the government exits defaults with a debt level independent from the level of defaulted debt $\left(b_{R}\right)$ simplifies the analysis: the value of defaulting is independent from the level of defaulted debt (as in most previous quantitative studies of sovereign default, which assume zero recovery of debt in default). However, in a model with long-term debt, this assumption gives the government incentives to issue an infinite amount of debt before defaulting, which would allow for a large increase in consumption. ${ }^{5}$ In order to avoid this problem, we assume that the government cannot sell defaultable bonds with a price lower than $\underline{q}$. We choose a value of $\underline{q}$ that eliminates consumption booms before defaults. The chosen value is also rarely binding, and allows for debt issuances at the sovereign spreads observed in the data (see Section III.).

\section{A. Recursive formulation}

We now describe the recursive formulation of the government's optimization problem. Let $e$ denote the number of non-defaultable bonds (Eurobonds) the government must pay, and $\bar{e}_{R}$ and $\bar{e}_{D}(e)$ denote the limit to the number of non-defaultable bonds the government can issue when it is not in default and when it is in default, respectively.

Let $V$ denote the value function of a government that is not currently in default. For any defaultable bond price function $q$, the function $V$ satisfies the following functional equation:

$$
V(b, e, y)=\max \left\{V_{R}(b, e, y), V_{D}(e, y)\right\}
$$

\footnotetext{
${ }^{4}$ Sovereign debt contracts often contain an acceleration clause and a cross-default clause. The first clause allows creditors to call the debt they hold in case the government defaults on a payment. The cross-default clause states that a default in any government obligation constitutes a default in the contract containing that clause. These clauses imply that after a default event, future debt obligations become current.

${ }^{5}$ Hatchondo et al. (2014b) present a four-period model that features this problem. Yue (2010) and Benjamin and Wright (2008) present models of defaultable-debt exchanges with one-period bonds.
} 
where the government's value of repaying is given by

$$
\begin{aligned}
& V_{R}(b, e, y)=\max _{b^{\prime} \geq 0, e^{\prime} \geq 0, c \geq 0}\left\{u(c)+\beta \mathbb{E}_{y^{\prime} \mid y} V\left(b^{\prime}, e^{\prime}, y^{\prime}\right)\right\}, \\
& \text { subject to } \\
& c=y-b-e+q\left(b^{\prime}, e^{\prime}, y\right)\left[b^{\prime}-(1-\delta) b\right]+\frac{e^{\prime}}{1+r}, \\
& e^{\prime} \leq \bar{e}_{R}, \\
& b^{\prime}>(1-\delta) b \text { only if } q\left(b^{\prime}, e^{\prime}, y\right) \geq \underline{q} .
\end{aligned}
$$

Since the value of being in default $V_{D}$ does not depend on the debt level, the value of having the opportunity to end the default by paying $b_{R}$ is equal to the value of starting the period out of default with debt $b_{R}$. Thus, the value of defaulting is given by:

$$
V_{D}(e, y)=\max _{e^{\prime} \geq 0, c \geq 0} u(c)+\beta \mathbb{E}_{y^{\prime} \mid y}\left[(1-\psi) V_{D}\left(e^{\prime}, y^{\prime}\right)+\psi V\left(b_{R}, e^{\prime}, y^{\prime}\right)\right]
$$

subject to

$$
\begin{aligned}
& c=y-\phi(y)-e+\frac{e^{\prime}}{1+r}, \\
& e^{\prime} \leq \bar{e}_{D}(e) .
\end{aligned}
$$

The solution to the government's problem yields decision rules for default $\hat{d}$, next-period defaultable debt $\hat{b}$, next-period non-defaultable bonds when the government repays $\hat{e}_{R}$, next-period non-defaultable bonds when the government is in default $\hat{e}_{D}$, and consumption $\hat{c}_{R}$ and $\hat{c}_{D}$. The default rule $\hat{d}$ is equal to 1 if the government defaults, and is equal to 0 otherwise. In a rational expectations equilibrium (defined below), investors use these decision rules to price debt contracts. Because investors are risk neutral, the bond-price function solves the following functional equation:

$$
q\left(b^{\prime}, e^{\prime}, y\right)(1+r)=\mathbb{E}_{y^{\prime} \mid y}\left\{\left[1-\hat{d}\left(b^{\prime}, e^{\prime}, y^{\prime}\right)\right]\left[1+(1-\delta) q\left(b^{\prime \prime}, e^{\prime \prime}, y^{\prime}\right)\right]+\hat{d}\left(b^{\prime}, e^{\prime}, y^{\prime}\right) q_{D}\left(b^{\prime}, e_{D}^{\prime \prime}, y^{\prime}\right)\right\}
$$

where

$$
\begin{aligned}
q_{D}\left(b, e^{\prime}, y\right)(1+r)= & \mathbb{E}_{y^{\prime} \mid y}\left\{\left[(1-\psi)+\psi \hat{d}\left(b_{R}, e^{\prime}, y^{\prime}\right)\right] q_{D}\left(b, e_{D}^{\prime \prime}, y^{\prime}\right)\right. \\
& \left.+\psi\left[1-\hat{d}\left(b_{R}, e^{\prime}, y^{\prime}\right)\right] \frac{b_{R}}{b}\left[1+(1-\delta) q\left(b_{R}^{\prime \prime}, e_{R}^{\prime \prime}, y^{\prime}\right)\right]\right\}
\end{aligned}
$$

denotes the price of a defaulted bond, and

$$
\begin{aligned}
b^{\prime \prime} & =\hat{b}\left(b^{\prime}, e^{\prime}, y^{\prime}\right) \\
e^{\prime \prime} & =\hat{e}_{R}\left(b^{\prime}, e^{\prime}, y^{\prime}\right) \\
b_{R}^{\prime \prime} & =\hat{b}\left(b_{R}, e^{\prime}, y^{\prime}\right) \\
e_{R}^{\prime \prime} & =\hat{e}_{R}\left(b_{R}, e^{\prime}, y^{\prime}\right) \\
e_{D}^{\prime \prime} & =\hat{e}_{D}\left(e^{\prime}, y^{\prime}\right)
\end{aligned}
$$


Equation (4) indicates that in equilibrium, for a risk-neutral investor, the value of selling a defaultable bond today and investing in a risk-free asset (left-hand side of the equation) has to be equal to the expected value of keeping the bond (right-hand side of the equation). If the investor keeps the bond and the government does not default next period, he first receives a one unit coupon payment and then sell the bonds at market price, which is equal to $(1-\delta)$ times the price of a bond issued next period. If the government defaults next period, the investor can still sell the defaulted bond at $q_{D}$.

\section{B. Recursive equilibrium}

A Markov Perfect Equilibrium is characterized by

1. a set of value functions $V, V_{R}$ and $V_{D}$,

2. rules for default $\hat{d}$, next-period defaultable debt $\hat{b}$, next-period non-defaultable bonds $\hat{e}_{R}$ and $\hat{e}_{D}$, and consumption $\hat{c}_{R}$ and $\hat{c}_{D}$,

3. and a bond price function $q$,

such that:

i. given a bond price function $q ;\left\{V, V_{R}, V_{D}, \hat{d}, \hat{b}, \hat{e}_{R}, \hat{e}_{D}, \hat{c}_{R}, \hat{c}_{D}\right\}$ solve Bellman equations (1), (2), and (3).

ii. given policy rules $\left\{\hat{d}, \hat{b}, \hat{e}_{R}, \hat{e}_{D}\right\}$, the bond price function $q$ satisfies condition (4).

\section{Calibration}

The utility function displays a constant coefficient of relative risk aversion form, i.e.,

$$
u(c)=\frac{c^{1-\gamma}-1}{1-\gamma}, \text { with } \gamma \neq 1
$$

The endowment process follows:

$$
\log \left(y_{t}\right)=(1-\rho) \mu+\rho \log \left(y_{t-1}\right)+\varepsilon_{t},
$$

with $|\rho|<1$, and $\varepsilon_{t} \sim N\left(0, \sigma_{\epsilon}^{2}\right)$.

Following Arellano (2008), we assume the cost of defaulting increases more than proportionally with income. This is a property of the endogenous default cost in Mendoza and Yue (2012) and, as shown by Chatterjee and Eyigungor (2012), allows the equilibrium 
default model to match the behavior of the sovereign spread in the data. Since sovereign defaults are associated with disruptions in credit to the private sector, it is natural to assume that the cost of these events is higher in good times when investment financed by credit is more productive. As Chatterjee and Eyigungor (2012), we assume a quadratic loss function for income during a default episode $\phi(y)=\max \left\{0, d_{0} y+d_{1} y^{2}\right\}$.

We calibrate the model without non-defaultable bonds $\left(\bar{e}_{R}=\bar{e}_{D}(e)=0\right)$ to replicate plausible features for Spain, an European economy with sovereign risk. Table 1 presents all parameter values. Most values are determined without using the model simulations. A period in the model refers to a quarter, and the risk-free interest rate is set equal to 1 percent. The coefficient of relative risk aversion is set equal to 2 , a standard value in quantitative business cycle and sovereign default studies (García-Cicco et al., 2010, Alvarez-Parra et al., 2013). The discount factor $\beta$ is set equal to 0.97 , which is within the range of values used in studies of sovereign default (Arellano and Ramanarayanan, 2012, Chatterjee and Eyigungor, 2012, Hatchondo et al., 2014a).

We assume that the probability of regaining access to capital markets $(\psi)$ is 0.282 . Following Arellano (2008), this is a standard value in the literature and is also in the range of estimates reported by Gelos et al. (2011). The stochastic process for income is estimated from the series of Spain's GDP for the periods of 1970Q1-2012Q3. We set $\delta=2.75 \%$. With this value, bonds have an average duration of 6 years in the simulations, which is the average duration of sovereign debt for Spain between 2009 and 2012 (the crisis period we use to determine the sovereign debt and spread targets). ${ }^{6}$

The assumed value of $\underline{q}$ implies that the sovereign cannot pay a spread higher than 3.6 percent when it issues debt (the spread can be higher than 3.6 percent in the simulations but the government cannot issue debt in periods when the spread is higher than 3.6 percent). This spread is higher than the maximum spread paid by European countries during the crisis (Trebesch and Wright, 2013). The limit $\underline{q}$ achieves its objective of eliminating consumption booms in the periods preceding defaults, and is only binding in 1.4 percent of the simulation periods.

As is standard in quantitative models of sovereign default, we calibrate the value of the parameters of the income cost of defaulting $\left(d_{0}\right.$ and $\left.d_{1}\right)$ targeting the mean levels of debt and sovereign spreads. Choosing these targets for European economies currently facing sovereign risk is difficult: the introduction of the euro seem to have had significant temporary effects on debt and spread dynamics making it difficult to infer the future long-run levels of these variables from past data. In the data, the levels of both sovereign debt and spread display a U-shape, bottoming out before the crisis. Explaining such dynamics is beyond the scope of this paper and outside the reach of its stationary model. We choose the targets guided by the data for Spain during the crisis (admittedly a small non-stationary sample), which delivers values we see as plausible for European economies. For Spain, the mean debt-to-GDP ratio between 2009 and 2012 is 67 percent. ${ }^{7}$ The mean

\footnotetext{
${ }^{6}$ We use the Macaulay definition of duration that, with the coupon structure in this paper, is given by $D=\frac{1+r^{*}}{\delta+r^{*}}$, where $r^{*}$ denotes the constant per-period yield delivered by the bond.

${ }^{7}$ While debt levels are higher in other European countries, our target is for the mean debt level in the
} 
Table 1: Parameter values.

\begin{tabular}{lcc}
\hline Risk-free rate & $r$ & $1 \%$ \\
Risk aversion & $\gamma$ & 2 \\
Discount factor & $\beta$ & 0.97 \\
Probability of reentry after default & $\psi$ & 0.282 \\
Income autocorrelation coefficient & $\rho$ & 0.8 \\
Standard deviation of innovations & $\sigma_{\epsilon}$ & $1 \%$ \\
Mean log income & $\mu$ & $(-1 / 2) \sigma_{\epsilon}^{2}$ \\
Debt duration & $\delta$ & 0.0275 \\
Price cap & $\underline{q}$ & 0.8 \\
Income cost of defaulting & $\underline{d_{0}}$ & -1.9 \\
Income cost of defaulting & $d_{1}$ & 2.25 \\
Default haircut & $b_{R}$ & 0.034 \\
\hline
\end{tabular}

sovereign spread during that period is 1.4 percent for 12 month bonds and 2.4 percent for 15 year bonds. We set $d_{0}=-1.9$ and $d_{1}=2.25$, and obtain a mean debt-to-income ratio of 66 percent and a mean spread of 2.0 percent in the simulations. ${ }^{8}$ We set $b_{R}=0.034$, which implies an average haircut for defaulted debt in the simulations of 66 percent, consistent with the average haircut of 65 percent reported by Cruces and Trebesch (2013) for debt restructurings with reductions in face value (as the ones we model).

\section{Results}

We solve the model using spline interpolation over debt levels and linear interpolation over endowment levels. Hatchondo et al. (2010) discuss the advantage of using interpolation in models of equilibrium default. We solve for the equilibrium of the finite-horizon version of our economy. We then increase the number of periods of the finite-horizon economy until

simulations, and one could expect debt levels in these countries will decline.

${ }^{8}$ In the simulations, in order to compute the sovereign spread implicit in a bond price, we compute the yield $i$ an investor would earn if it holds the bond to maturity and no default is declared. This yield satisfies

$$
q_{t}=\sum_{j=1}^{\infty} \frac{(1-\delta)^{j-1}}{(1+i)^{j}} .
$$

The sovereign spread is the difference between the yield $i$ and the risk-free rate $r$. We report the annualized spread

$$
r_{t}^{s}=\left(\frac{1+i}{1+r}\right)^{4}-1 .
$$

Debt levels are calculated as the present value of future payment obligations discounted at the risk-free rate, i.e., $b^{\prime}(\delta+r)^{-1}$. Moments for the simulations correspond to the mean value of each moment in 250 simulation samples, with each sample including 120 periods (30 years) without a default episode, and starting at least five years after a default. 
Table 2: Effects of introducing non-defaultable bonds

the value and bond-price functions for the first and second periods of this economy are sufficiently close. We use the first-period equilibrium functions as the infinite-horizon-economy equilibrium functions.

\section{A. Effects of introducing non-defaultable bonds}

We first solve the model without non-defaultable bonds $\left(\bar{e}_{R}=\bar{e}_{D}(e)=0\right)$. Then, we measure the effects of an unanticipated announcement explaining that from now on, the government will be able to issue non-defaultable bonds. In particular, it is announced that the constraints on non-defaultable bond issuances change from $\bar{e}_{R}=\bar{e}_{D}(e)=0$ to $\bar{e}_{R}=0.4$ and $\bar{e}_{D}(e)=e$. That is, it is announced that (i) the government can issue non-defaultable bonds for up to 10 percent of trend annual income if it is not in default, and (ii) when in default, the government can rollover existing non-defaultable bonds but cannot increase the level of its non-defaultable debt (the role of the latter assumption is discussed in Section F.). We choose the 10 percent limit for non-defaultable debt because: (i) this limit is at the lower end of limits discussed in Eurobond proposals, and (ii) we will show that this limit is enough to reduce sovereign risk significantly and to finance the debt reduction necessary to implement immediately a defaultable-debt limit that eliminates sovereign risk (assuming the government can fully commit to this limit).

Table 2 shows that introducing non-defaultable bonds produces immediately a significant reduction of the sovereign spread, and that the reduction is higher when default risk is higher. The table presents results for three states with different spread levels before the introduction of Eurobonds, reflecting different levels of default risk. For all cases the debt level is equal to 66 percent of trend income. The medium, highest, and lowest risk cases correspond to income levels equal to the mean level, and two and a half standard deviations below and above the mean level, respectively.

Since the effects of introducing non-defaultable bonds on the sovereign spread presented in Table 2 are computed before the government takes any action, these effects reflect the lenders' expectations about future declines of the defaultable debt level. Crucially, since we assume defaultable debt is long-term, the current spread does not only depend on the current debt level but also on future debt levels (and future default decisions). Figure 1 shows that the stock of defaultable debt declines on average in the first periods that follow the introduction of non-defaultable debt, which reduces the incentives to default in those periods. 

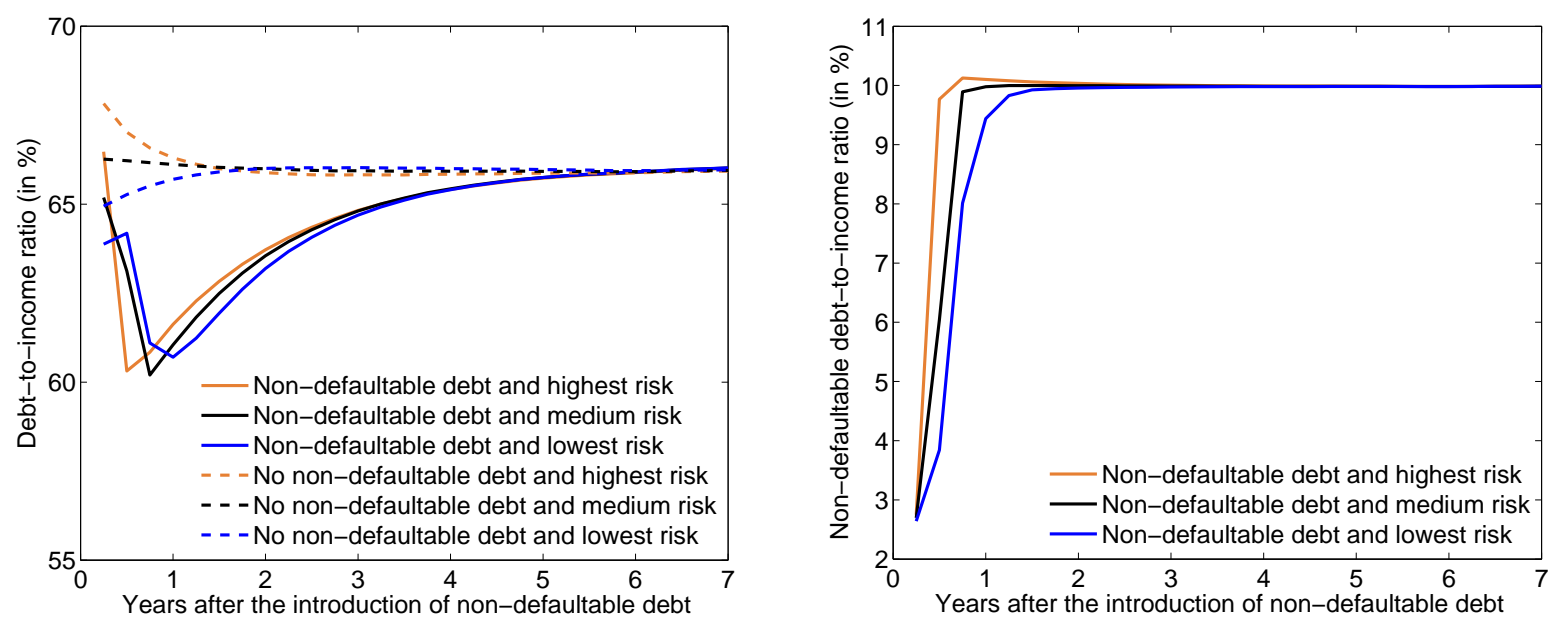

Figure 1: Debt after the introduction of non-defaultable bonds. The figure presents the mean defaultable-debt-to-income ratio $\left(\frac{b^{\prime} /(\delta+r)}{4 y}\right)$ and non-defaultable-debt-to-income ratio $\left(\frac{e^{\prime} /(1+r)}{4 y}\right)$ during transitions that follow the introduction of non-defaultable bonds, for samples without defaults. Solid lines present the mean of transition paths for economies where the government can issue non-defaultable bonds. Dashed lines present the mean of transition paths for economies without non-defaultable bonds.

The introduction of non-defaultable bonds could also avoid an imminent default. Figure 2 presents the government's equilibrium default decision in the economy without non-defaultable bonds and in the economy with non-defaultable bonds when the initial level of non-defaultable bonds is equal to zero (i.e., $\hat{d}(b, 0, y))$. The figure shows that there is a set of combinations of income and defaultable debt levels for which the government would default if non-defaultable bonds are not introduced but would not default if non-defaultable bonds are introduced. Furthermore, the introduction of non-defaultable bonds never triggers a default: there is no combination of income and defaultable debt levels for which the government would default if non-defaultable bonds are introduced but would not default if non-defaultable bonds are not introduced. A government that would default without the introduction of non-defaultable bonds may choose to pay if non-defaultable bonds are introduced because paying would allow it to issue non-defaultable bonds immediately.

Table 2 shows that welfare gains from introducing non-defaultable bonds may be significant. We measure welfare gains as the constant proportional change in consumption that would leave a consumer indifferent between living in the economy without non-defaultable bonds and living in the economy with non-defaultable bonds. This consumption change is given by

$$
\left(\frac{V_{E}(b, 0, y)}{V_{N}(b, y)}\right)^{\frac{1}{1-\gamma}}-1,
$$

where $V_{E}$ and $V_{N}$ denote the value functions with non-defaultable bonds $\left(\bar{e}_{R}=0.4\right.$ and 


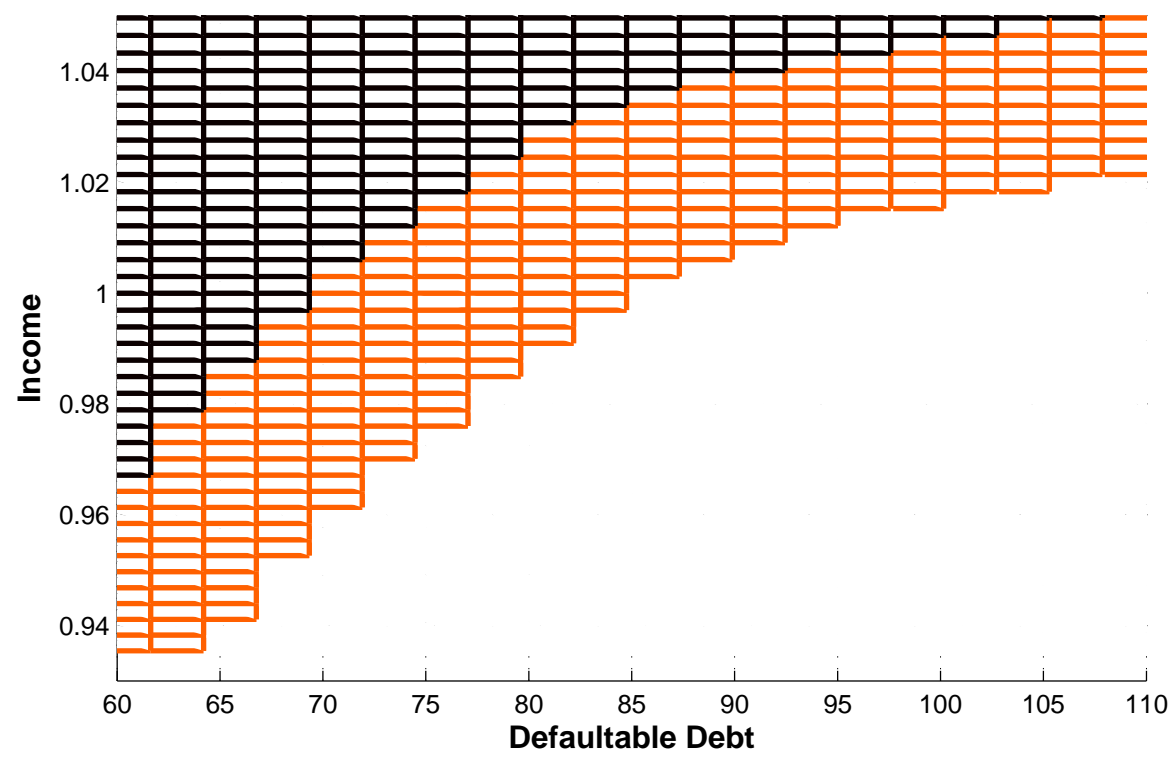

Figure 2: Default decision with and without non-defaultable bonds. For the economy with nondefaultable bonds, the initial level of non-defaultable bonds is equal to zero (i.e., when $e=0$ ). The figure presents combinations of income and defaultable debt levels for which: (i) the government would pay its debt with or without non-defaultable bonds (black area), (ii) the government would default only if non-defaultable bonds are not introduced (orange area), and (iii) the government would default with or without non-defaultable bonds (white area). (There is no combination of income and defaultable debt levels for which the government would default only if non-defaultable bonds are introduced.)

$\bar{e}_{D}(e)=e$ ) and without non-defaultable bonds $\left(\bar{e}_{R}=\bar{e}_{D}(e)=0\right)$. Thus, a positive welfare gain means that agents prefer the economy with non-defaultable bonds.

As is standard in models of sovereign default à la Eaton and Gersovitz (1981), government borrowing is limited by endogenous and binding borrowing constraints that arise because the government cannot commit to pay its debt. As illustrated by Figure 2, higher debt levels imply higher default probabilities, which are reflected in a higher borrowing cost, limiting the amount the government can borrow. Thus, the government benefits from the new borrowing opportunities implied by the introduction of non-defaultable debt.

It is likely that our model underestimate gains from lowering the sovereign spread. Several studies find evidence of a significant positive effect of a reduction of interest rates on productivity through the allocation of factors of production (see for instance, Mendoza and Yue, 2012). In light of these findings, gains from introducing a limited non-defaultable sovereign financing option may be larger than the ones we compute. 
Table 3: Effects of introducing non-defaultable debt with a defaultable-debt buyback

\begin{tabular}{lccc}
\hline & Highest risk & Medium risk & Lowest risk \\
Spread before the buyback & $2.9 \%$ & $1.9 \%$ & $1.6 \%$ \\
Spread after the buyback & $1.3 \%$ & $1.2 \%$ & $1.2 \%$ \\
Defaultable debt bought back (\% of trend income) & $11.8 \%$ & $11.7 \%$ & $11.7 \%$ \\
Welfare gain from the buyback & $0.7 \%$ & $0.8 \%$ & $0.8 \%$ \\
\hline
\end{tabular}

\section{B. Debt buybacks}

In this section, we assume that when non-defaultable bonds are introduced, the government issues non-defaultable bonds up to the imposed limit and uses the proceeds from this issuance to finance a buyback of defaultable debt. This capture the intent of some of the existing Eurobond proposals (Claessens et al., 2012). We consider the same three initial states presented in Table 2. The defaultable debt level at the end of the buyback period is given by

$$
b_{B}\left(b, \bar{e}_{R}, y\right)=b-\frac{\bar{e}_{R}}{(1+r)\left[1+(1-\delta) q\left(b_{B}\left(b, \bar{e}_{R}, y\right), \bar{e}_{R}, y\right)\right]},
$$

where $\bar{e}_{R}$ denotes the initial non-defaultable bond issuance and thus $\bar{e}_{R} /(1+r)$ denotes the proceeds from these issuances, and $1+(1-\delta) q\left(b_{B}\left(b, \bar{e}_{R}, y\right), \bar{e}_{R}, y\right)$ denotes the price at which a lender is willing to sell a defaultable bond (which equals the resources the lender would obtain if it does not sell his bond). ${ }^{9}$

Table 3 shows that non-defaultable bonds issuances for 10 percent of trend income would allow the government to buy back defaultable debt for almost 12 percent of trend income. This defaultable debt reduction is larger than the one observed with the introduction of non-defaultable bonds as a new source of financing (Figure 1).

The model features a buyback boondoggle à la Bulow and Rogoff $(1988,1991)$ but the additional increase in sovereign bond prices implied by the debt buyback is minimal: the spread reduction at the moment non-defaultable debt is introduced is only slightly higher when the government is forced to use non-defaultable debt to buy back defaultable debt (1.6 percent instead of 1.5 percent). The spread reductions is only slightly larger with the buyback because lenders anticipate that the government will quickly increase the level of defaultable debt after the buyback. Crucially, since we model defaultable debt as long-term debt, the price of debt depends on the expected future debt levels (an the implied default probabilities). Figure 3 presents the defaultable debt dynamics after the buyback and shows that these dynamics are very similar to the ones obtained when the government is not forced to use non-defaultable bonds to buy back debt (Figure 1). Of course, welfare gains are lower with the buyback: we always give the government the choice to buy back defaultable debt and, therefore, the government cannot benefit from being forced to do so.

\footnotetext{
${ }^{9}$ The discussion above assumes that the government does not want to default after the buyback, which is the case for the three initial states we study.
} 


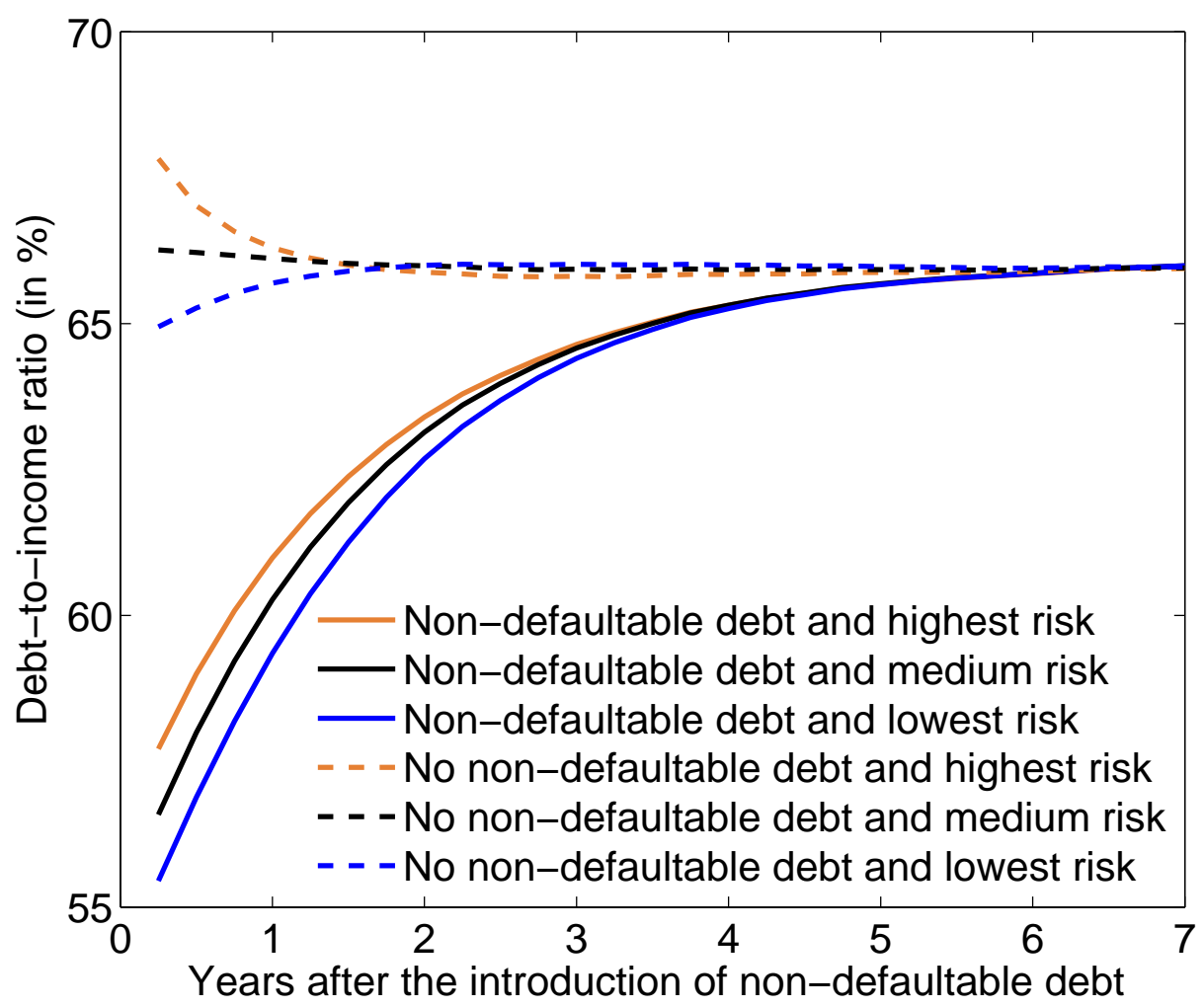

Figure 3: Debt after the introduction of non-defaultable bonds through a buyback. The figure presents the mean defaultable-debt-to-income ratio $\left(\frac{b^{\prime} /(\delta+r)}{4 y}\right)$ during transitions that follow the introduction of non-defaultable bonds through a defaultable debt buyback, for samples without defaults. Solid lines present the mean of transition paths for economies where the government can issue non-defaultable bonds. Dashed lines present the mean of transition paths for economies without non-defaultable bonds.

Limitations of debt buybacks are well understood. It is often argued that debt buybacks are only sensible if the government is able to obtain some compensation from bondholders. For instance, Bulow and Rogoff (1988) conclude that "Buybacks can be justified only if the country negotiates substantial concessions or compensation for undertaking the repurchase." In the next subsection, we study the effects of voluntary debt exchanges in which the government obtains concessions from bondholders, who still are not worse off because of the capital gains implied by the decline of defaultable debt.

\section{C. "Voluntary" debt exchanges}

In this subsection, we study the effects of introducing non-defaultable bonds through a Pareto-improving "voluntary" debt exchange. This is, a debt exchange that reduces the government indebtedness (i.e., has a positive face-value haircut) without affecting the total 
market value of bondholders debt claims. ${ }^{10}$ In particular, we focus on the extreme case in which the government is able to capture all bondholders' capital gains that arise because of the introduction of non-defaultable debt. The previous subsection studies the other extreme case: debt buybacks in which bondholders enjoy all capital gains that arise because of the introduction of non-defaultable debt. Voluntary debt exchanges are prominent in policy discussions (Claessens and Dell'Ariccia, 2011) and are frequently observed in practice (Claessens and Diwan, 1994; Hatchondo et al., 2014b).

Suppose that, at the beginning of the period in which non-defaultable bonds are introduced, the government extends the following take-it-or-leave-it offer to bondholders: for each (defaultable debt) coupon payment due this period, bondholders would receive $\bar{e}_{R} / b$ non-defaultable bonds to be paid next period plus $b_{E} / b$ defaultable bonds that start paying coupons in the current period. If bondholders do not accept this offer, non-defaultable bonds will not be introduced. The government offers the level of defaultable debt $b_{E}$ that makes bondholders indifferent between accepting or not the offer. Thus, the government can capture all gains from introducing non-defaultable bonds.

Considering the same three initial states studied in previous subsections (for which the government does not default), the post-exchange quantity of defaultable bonds $b_{E}$ is such that

$$
\frac{\bar{e}_{R}}{b(1+r)}+\frac{b_{E}\left(b, \bar{e}_{R}, y\right)\left[1+(1-\delta) q\left(b_{E}\left(b, \bar{e}_{R}, y\right), \bar{e}_{R}, y\right)\right]}{b}=1+(1-\delta) q_{N}\left(\hat{b}_{N}(b, y), y\right)
$$

where $q_{N}$ and $\hat{b}_{N}$ denote the bond price and government's borrowing functions in the economy without non-defaultable bonds (i.e., where $\bar{e}_{R}=\bar{e}_{D}(e)=0$ and, therefore, we do not need $e$ as a state variable). The right-hand-side of equation (6) represents what a bondholder would obtain if he rejects the exchange, for the holding of each promise to pay one unit in the current period (and the corresponding future payment promises). The left-hand-side of equation (6) represents what this bondholder would obtain if he accepts the exchange.

The difference between the debt buyback studied in Section B. and the voluntary debt exchanges studied in this section is apparent from comparing equations (5) and (6), which must hold with a buyback or a voluntary debt exchange, respectively. Equation (5) can be written as

$$
\frac{\bar{e}_{R}}{(1+r)}+b_{B}\left(b, \bar{e}_{R}, y\right)\left[1+(1-\delta) q\left(b_{B}\left(b, \bar{e}_{R}, y\right), \bar{e}_{R}, y\right)\right]=b\left[1+(1-\delta) q\left(b_{B}\left(b, \bar{e}_{R}, y\right), \bar{e}_{R}, y\right)\right] .
$$

The left-hand side of equation (7) is the value of sovereign debt after the introduction of non-defaultable bonds with a buyback. The right-hand side of equation (7) is the value of the debt stock before the introduction of non-defaultable debt evaluated with the price of

\footnotetext{
${ }^{10}$ Hatchondo et al. (2014b) study voluntary debt exchanges as a normal feature of sovereign debt dynamics. Here, we focus on voluntary debt exchanges as an instrument for introducing a new source of financing.
} 
Table 4: Effects of introducing non-defaultable bonds with a "voluntary" debt exchange

Spread before the exchange

Spread after the exchange

Reduction in defaultable debt (\% of trend income)

Welfare gain from the exchange

\begin{tabular}{ccc} 
Highest risk & Medium risk & Lowest risk \\
$2.9 \%$ & $1.9 \%$ & $1.6 \%$ \\
$1.2 \%$ & $1.2 \%$ & $1.1 \%$ \\
$13.8 \%$ & $13.3 \%$ & $12.8 \%$ \\
$1.1 \%$ & $1.1 \%$ & $1.1 \%$ \\
\hline
\end{tabular}

defaultable bonds that prevails after non-defaultable debt is introduced. Equation (6) can be written as

$$
\frac{\bar{e}_{R}}{(1+r)}+b_{E}\left(b, \bar{e}_{R}, y\right)\left[1+(1-\delta) q\left(b_{E}\left(b, \bar{e}_{R}, y\right), \bar{e}_{R}, y\right)\right]=b\left[1+(1-\delta) q_{N}\left(\hat{b}_{N}(b, y), y\right)\right] .
$$

The left-hand side of equation (8) is the value of sovereign debt after the introduction of non-defaultable debt with a voluntary debt exchange. The right-hand side of equation (8) is the value of the debt stock before the introduction of non-defaultable debt evaluated with the price of defaultable bonds that would prevail without the introduction of non-defaultable debt. Since the introduction of non-defaultable bonds increases the price of defaultable bonds, the right-hand side of equation (7) is higher than the right-hand side of equation (8). Thus, the left-hand side of equation (7) is higher than the left-hand side of equation (8), which implies that introducing non-defaultable bonds with a voluntary debt exchange allows for a larger debt reduction than introducing non-defaultable bonds with a buyback $\left(b_{E}\left(b, \bar{e}_{R}, y\right)<b_{B}\left(b, \bar{e}_{R}, y\right)\right) .^{11}$

Table 4 shows that the additional defaultable debt reduction from introducing non-defaultable debt with a voluntary debt exchange instead of a buyback is between one and two percent of trend income. These savings from using debt exchanges over buybacks are roughly consistent with estimates by Claessens and Diwan (1994).

Table 4 shows that the additional defaultable debt reduction from introducing non-defaultable debt with a voluntary debt exchange instead of a buyback is larger when default risk is higher prior to the introduction of non-defaultable debt. When default risk is higher, additional debt reductions from the exchange are larger because bondholders' capital gains from the introduction of non-defaultable bonds are larger, and the exchange allows the government to capture these gains.

\section{Long-run effect of non-defaultable bonds on default risk}

Figure 4 shows that the effect of the introduction of non-defaultable bonds on default risk (and thus on spreads) declines over time. In particular, the introduction of non-defaultable bonds does not have a significant effect on default risk after five years. The figure presents the case in which non-defaultable bonds are introduced without a buyback or a voluntary

\footnotetext{
${ }^{11}$ This assumes that the price of a defaultable bond is a decreasing function of the stock of defaultable debt, which as expected is always the case with our calibration of the model.
} 
exchange. But the modality of the introduction of non-defaultable bonds has negligible effects of debt and spread dynamics after a couple of years and is inconsequential in the long run.

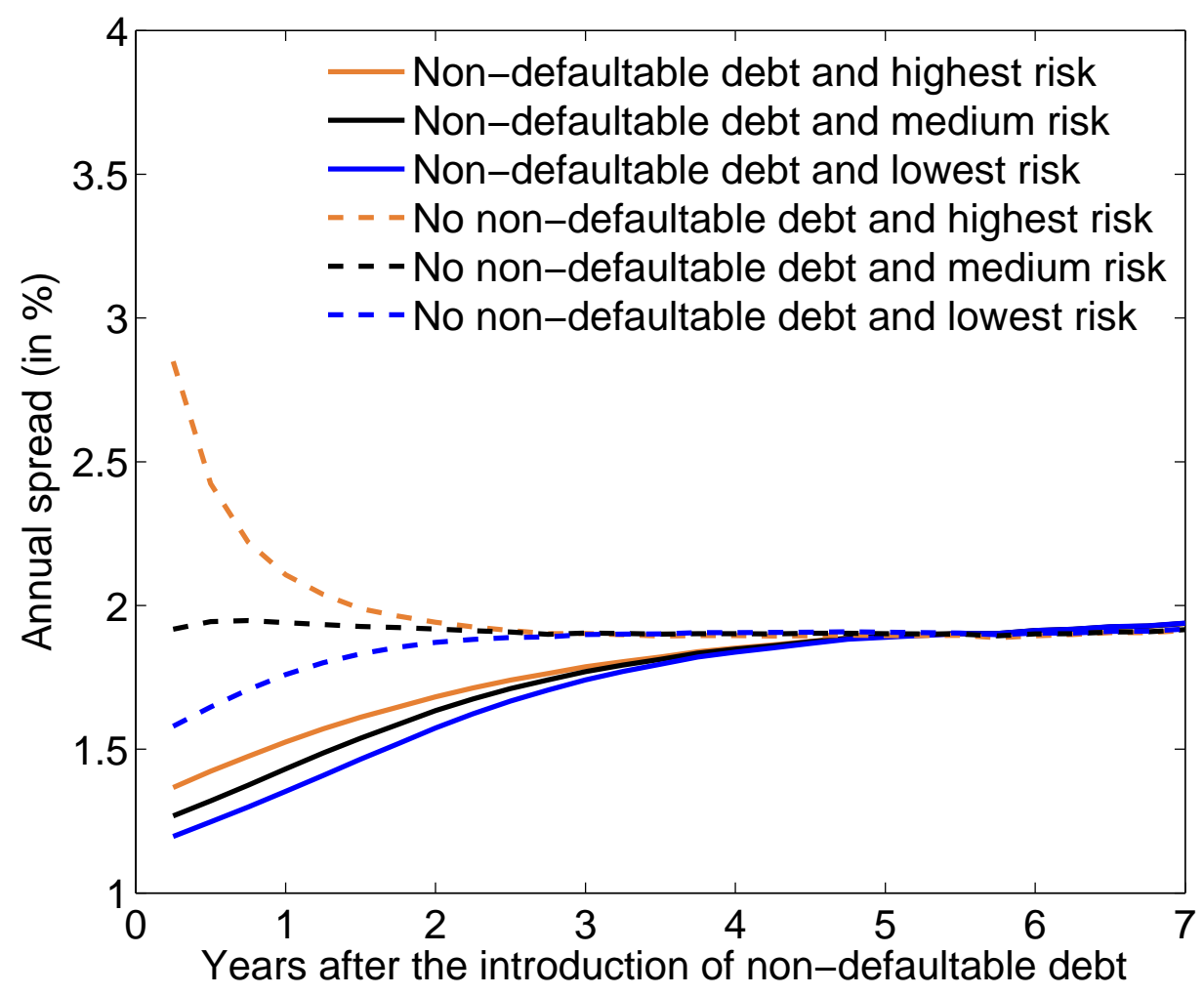

Figure 4: Sovereign spread after the introduction of non-defaultable bonds. Solid lines present the mean of transition paths for economies where the government can issue non-defaultable bonds. Dashed lines present the mean of transition paths for economies without non-defaultable bonds. In both cases, we use samples without defaults.

Spread dynamics presented in Figure 4 are consistent with the debt dynamics presented in Figure 1. The first year after non-defaultable bonds are introduced as a new source of financing, the government does not issue defaultable debt, causing a decline in the defaultable debt level, and thus a decline in spreads. But after one year, the financing with non-defaultable bond is exhausted and the government starts increasing the level of defaultable debt. On average, in five years, the level of defaultable debt returns to the level observed prior to the introduction of non-defaultable debt.

The negligible long-run effect of non-defaultable bonds on default risk is not surprising. Figure 1 shows that less than two years after the introduction of non-defaultable bonds, the government hits the 10-percent limit. The borrowing opportunities and incentives to borrow for a government that has already issued non-defaultable bonds up to the 10-percent limit are very similar to those in the economy without non-defaultable bonds. 
The main difference is that in the economy with non-defaultable bonds, the government has to pay interest for these bonds. But this only represents 0.4 percent of its trend income (a 4 percent interest rate on debt for 10 percent of trend income). Since the government has to make this payment irrespectively of whether it chooses to default, this payment does not change significantly the government's default decisions. Thus, this payment does not change significantly the government's borrowing opportunities (i.e., the spread it would have to pay for each level of defaultable debt it chooses). Given almost identical borrowing opportunities, the small payment of interest on non-defaultable bonds has negligible effects on the government's willingness to borrow and pay for default risk.

\section{E. Voluntary debt exchanges with a limit for defaultable debt}

Potential complementarities between Eurobonds and fiscal rules have long been recognized. For example, Delpla and von Weizscker (2010) discuss binding fiscal rules as prerequisite for Eurobond (Blue Bond) issuances. The German Council of Economic Experts discusses the mutualization of sovereign debt as a temporary remedy until fiscal rule targets are achieved and propose requiring participating countries to introduce debt brakes in their constitutions, following the ones in Germany and Switzerland (Bofinger et al., 2011). Part of the motivation for the combination of Eurobond issuances and fiscal rules is mitigating moral hazard concerns. We show that even abstracting from moral hazard concerns, there is still a role for fiscal rules.

This subsection presents the effects of introducing non-defaultable bonds together with a limit on defaultable debt (a fiscal rule). In particular, we assume that non-defaultable bonds issuances for 10 percent of trend income are used to finance a voluntary debt exchange while imposing immediately a limit of 55 percent of trend income for defaultable debt. We choose this debt limit because we will show that: (i) non-defaultable bonds are enough to finance the debt reduction necessary to implement this limit immediately and (ii) this limit is enough to eliminate default risk. ${ }^{12}$

Table 5 shows that default risk disappears immediately after the limit for defaultable debt is introduced (financed with the introduction of non-defaultable bonds). The introduction of non-defaultable bonds allows the government to reduce the level of defaultable debt below the 55 percent limit. Thus, after the introduction of non-defaultable bonds, the government finances a significant expansion of consumption by increasing the level of defaultable debt to the 55 percent limit. Table 5 also shows that welfare gains are larger when the introduction of non-defaultable bonds is combined with a debt limit. In the long

\footnotetext{
${ }^{12}$ Since the debt limit forces the government to lower the level of defaultable debt from 66 percent to 55 percent, imposing this limit without financing the defaultable-debt reduction with non-defaultable debt would imply a very large decline in consumption and it would be likely to trigger a default. Hatchondo et al. (2011) present a more detailed discussion of the effects of committing to fiscal rules in a sovereign default framework and show how gains from introducing fiscal rules arise because rules allow the government to mitigate the debt dilution problem. Because we assume perfect commitment to the debt limit, and because the debt limit is implemented immediately after a debt restructuring, our results should not be compared with actual experiences with debt limits in Europe.
} 
Table 5: Effects of introducing non-defaultable bonds with a limit for defaultable debt

Spread before the exchange and the debt limit Spread after the exchange and the debt limit Reduction in defaultable debt (\% of trend income) Welfare gain from the exchange and the debt limit

\begin{tabular}{ccc} 
Highest risk & Medium risk & Lowest risk \\
$2.9 \%$ & $1.9 \%$ & $1.6 \%$ \\
$0.0 \%$ & $0.0 \%$ & $0.0 \%$ \\
$15.5 \%$ & $15.1 \%$ & $14.7 \%$ \\
$1.4 \%$ & $1.3 \%$ & $1.3 \%$ \\
\hline
\end{tabular}

run, the government stays at the 55 percent defaultable debt limit, which implies that the sovereign spread stays at zero.

\section{F. Issuances of non-defaultable bonds during defaults}

The ability of governments in default to increase Eurobond debt is often a central element of Eurobond proposals. For instance, in the original Blue-red bond proposal, Delpla and von Weizscker (2010) argue that a government's ability to issue Eurobonds (blue bonds) should not be affected by a default on other sovereign debt. Part of the cost of defaulting is losing access to credit. This cost would be mitigated if the government could issue Eurobonds after defaulting. Thus, allowing governments in default to issue Eurobonds would make defaults a more attractive option. Delpla and von Weizscker (2010) argue that this would increase the cost of issuing defaultable (red) debt and, thus, would limit defaultable debt issuances (which we show in Subsection E. could be welfare enhancing).

We next measure the effects of allowing governments in default to increase non-defaultable debt in our model. We find that these effects are negligible. We solve the model assuming $\bar{e}_{D}(e)=\bar{e}_{R}=0.4$ instead of $\bar{e}_{D}(e)=e$ (as it was assumed throughout the paper). That is, we now assume default does not impose additional restrictions on non-defaultable bond issuances.

Comparing simulations of the model assuming either $\bar{e}_{D}(e)=0.4$ or $\bar{e}_{D}(e)=e$, we find that these assumptions on $\bar{e}_{D}$ have negligible effects on the mean defaultable-debt-to-income ratio (66 percent in both cases) and on the mean spread (2 percent in both cases). This is not surprising since, as shown in Figure 1, after the introduction of non-defaultable bonds, the government rapidly builds up its stock of non-defaultable debt until it hits the constraint. Therefore, assuming either $\bar{e}_{D}(e)=0.4$ or $\bar{e}_{D}(e)=e$ is inconsequential soon after the introduction of non-defaultable bonds. That is, since we can expect the government to exhaust its ability to issue non-defaultable bonds before defaulting, assuming that a default does not change the government's ability to increase the level of non-defaultable bonds is inconsequential.

Similarly, we find negligible effects of assuming $\bar{e}_{D}(e)=0.4$ instead of $\bar{e}_{D}(e)=e$ at the moment non-defaultable bonds are introduced. This is the case even when the government is not forced to use non-defaultable bonds for a buyback or a voluntary debt exchange (and, thus, it is not forced to leave the period in which non-defaultable bonds are 
introduced with the maximum level of those bonds). The reduction in spreads implied by the introduction of non-defaultable bonds is slightly lower with $\bar{e}_{D}(e)=0.4$, but the difference between the reductions with $\bar{e}_{D}(e)=e$ and $\bar{e}_{D}(e)=0.4$ is always less than 0.1 percent. This is again not surprising since default risk is low when non-defaultable bonds are introduced (as reflected in the low spreads in Figure 4) and the level of non-defaultable bonds debt quickly converges to 0.4 .

\section{Conclusions}

We show that simulations of a model of equilibrium sovereign risk indicate that relatively small issuances of non-defaultable bonds could result in significant reductions in sovereign risk and produce substantial welfare gains. When comparing different modalities for the introduction of non-defaultable bonds, we find that introducing these bonds through a buyback or a voluntary debt exchange would only result in a small additional reduction of sovereign risk. We also show that non-defaultable bonds would only lower sovereign risk in the long run when combined with fiscal rules that limit the issuance of defaultable debt.

These findings shed light on different aspects of proposals to introduce common euro-area sovereign bonds. However, since we do not consider the costs or difficulties of introducing these bonds, our results should not be interpreted as endorsing their introduction but rather as suggesting that it could be worth finding a way of dealing with these costs and difficulties. 


\section{References}

Aguiar, M. and Amador, M. (2013). 'Take the Short Route. How to repay and restructure sovereign debt with multiple maturities'. Manuscript.

Aguiar, M. and Gopinath, G. (2006). 'Defaultable debt, interest rates and the current account'. Journal of International Economics, volume 69, 64-83.

Alvarez-Parra, F., Brandao-Marques, L., and Toledo, M. (2013). 'Durable goods, financial frictions, and business cycles in emerging economies'. Journal of Monetary Economics, volume 60(6), 720-736.

Arellano, C. (2008). 'Default Risk and Income Fluctuations in Emerging Economies'. American Economic Review, volume 98(3), 690-712.

Arellano, C. and Ramanarayanan, A. (2012). 'Default and the Maturity Structure in Sovereign Bonds'. Journal of Political Economy, volume 120, no. 2, 187-232.

Benjamin, D. and Wright, M. L. J. (2008). 'Recovery Before Redemption? A Theory of Delays in Sovereign Debt Renegotiations'. Manuscript.

Bofinger, P., Feld, L. P., Franz, W., Schmidt, C. M., and Weder di Mauro, B. (2011). 'A European Redemption Pact'. VOX.

Boz, E. (2011). 'Sovereign Default, Private Sector Creditors, and the IFIs'. Journal of International Economics, volume 83, 70-82.

Brunnermeier, M. K., Garicano, L., Lane, P. R., Pagano, M., Reis, R., Santos, T., Thesmar, D., Van Nieuwerburgh, S., and Vayanos, D. (2011). 'European Safe Bonds (ESBies)'. Manuscript. Avialable at http://www.columbia.edu/ rr2572/papers/11-ESBies.pdf.

Bulow, J. and Rogoff, K. (1988). 'The Buyback Boondoggle'. Brookings Papers on Economic Activity, volume 1988, no. 2, 675-704.

Bulow, J. and Rogoff, K. (1991). 'Sovereign Debt Repurchases: No Cure for Overhang'. Quarterly Journal of Economics, volume 106.

Chatterjee, S. and Eyigungor, B. (2012). 'Maturity, Indebtedness and Default Risk'. American Economic Review, volume 102(6), 2674-2699.

Claessens, S. and Dell'Ariccia, G. (2011). 'Are buybacks an efficient way to reduce sovereign debt?' VOX.

Claessens, S. and Diwan, I. (1994). 'Recent experience with commercial bank debt reduction: Has the menu outdone the market?' World Development, volume 22, no. 2, 201-213.

Claessens, S., Mody, A., and Vallée, S. (2012). 'Paths to Eurobonds'. IMF Working Paper 12/172. 
Cruces, J. J. and Trebesch, C. (2013). 'Sovereign Defaults: The Price of Haircuts'. American Economic Journal: Macroeconomics, forthcoming.

Dellas, H. and Niepelt, D. (2013). 'Credibility For Sale'. Manuscript.

Delpla, J. and von Weizscker, J. (2010). 'The Blue Bond Proposal'. Bruegel Policy Brief 2010/03.

Eaton, J. and Gersovitz, M. (1981). 'Debt with potential repudiation: theoretical and empirical analysis'. Review of Economic Studies, volume 48, 289-309.

EC (2014). 'Expert Group on Debt Redemption Fund and Eurobills: Final Report submitted on 31 March 2014'. European Commission. Avialable at http://ec.europa.eu/economy_finance/articles/governance/pdf/20140331_conclusion_en.pdf.

García-Cicco, J., Pancrazi, R., and Uribe, M. (2010). 'Real Business Cycles in Emerging Countries?' American Economic Review, volume 100, 2510-2531.

Gelos, G., Sahay, R., and Sandleris, G. (2011). 'Sovereign Borrowing by Developing Countries: What Determines Market Access?' Journal of International Economics, volume 83(2), 243254.

Hatchondo, J. C. and Martinez, L. (2009). 'Long-duration bonds and sovereign defaults'. Journal of International Economics, volume 79, 117 - 125.

Hatchondo, J. C., Martinez, L., and Roch, F. (2011). 'Fiscal rules and the sovereign default premium'. Manuscript. http://works.bepress.com/leonardo_martinez/18/.

Hatchondo, J. C., Martinez, L., and Sapriza, H. (2010). 'Quantitative properties of sovereign default models: solution methods matter'. Review of Economic Dynamics, volume 13, no. 4, 919-933.

Hatchondo, J. C., Martinez, L., and Sosa Padilla, C. (2014a). 'Debt dilution and sovereign default risk'. Manuscript. http://works.bepress.com/leonardo_martinez/17/.

Hatchondo, J. C., Martinez, L., and Sosa Padilla, C. (2014b). 'Voluntary Sovereign Debt Exchanges'. Journal of Monetary Economics, volume 61, 32-50.

Mendoza, E. and Yue, V. (2012). 'A General Equilibrium Model of Sovereign Default and Business Cycles'. The Quarterly Journal of Economics, volume 127 (2), 889-946.

Philippon, T. and Hellwig, C. (2011). 'Eurobills, not Eurobonds'. VOX.

Trebesch, C. and Wright, M. L. J. (2013). 'A Default Measure of Sovereign Default'. Mimeo.

Yue, V. (2010). 'Sovereign default and debt renegotiation'. Journal of International Economics, volume 80, no. 2, 176-187. 